\title{
Noniterative approach to the total asymmetric synthesis of 15-carbon polyketides and analogs with high stereodiversity*
}

\author{
Pierre Vogel ${ }^{\ddagger}$, Sandrine Gerber-Lemaire, Ana T. Carmona, \\ Kai Torsten Meilert, and Marc-Etienne Schwenter \\ Laboratory of Glycochemistry and Asymmetric Synthesis, Ecole Polytechnique
Fédérale de Lausanne (EPFL), BCH, CH-1015 Lausanne-Dorigny, Switzerland
}

Abstract: Starting from inexpensive furan and furfuryl alcohol, a noniterative approach to the synthesis of pentadeca-1,3,5,7,9,11,13,15-octols and their derivatives has been developed. The method relies upon the double [4+3]-cycloaddition of 1,1,3-trichloro-2-oxylallyl cation with 2,2'-methylenedifuran and conversion of the adducts into meso and ( \pm )-threo-1,1'-methylenebis (cis- and trans-4,6-dihydroxycyclohept-1-ene) derivatives. The latter undergo oxidative cleavage of their alkene moieties, generating 5-hydroxy-7-oxoaldehydes that are reduced diastereoselectively into either syn or anti-5,7-diols. Asymmetry is realized using either chiral desymmetrization with Sharpless asymmetric dihydroxylation or by kinetic resolution of polyols using lipase-catalyzed acetylations. All of the possible stereomeric pentadeca-1,3,5,7,9,11,13,15-octols and derivatives can be obtained with high stereoselectivity applying simple operations, thus demonstrating the high stereodiversity of this new, noniterative approach to the asymmetric synthesis of long-chain polyketides.

\section{INTRODUCTION}

A great variety of natural products of biological interest includes polyketide (1,3-polyoxo, 1,3-polyols, aldols) components [1], and several approaches to their synthesis have been proposed [2]. Inspired by the work of Lautens [3] and Hoffmann and coworkers [4], who have converted 8-oxabicyclo[3.2.1]oct-6-en-3-one into seven-carbon chain 1,3-polyols and analogs [5], and by that of Kaku et al. [6], who have transformed cyclohept-3-ene-1,6-diol into 1,3-polyols, we have proposed a new, noniterative asymmetric synthesis of long-chain 1,3-polyols starting from the now readily available 2,2'-methylenebis(furan) (1) [7]. This method involved a double [3+4]-cycloaddition between the 1,1,3-trichloro-2-oxyallyl cation and $\mathbf{1}$ (Scheme 1). After reductive work-up, a 45:55 mixture of meso2 and $( \pm$ )-threo-2 was obtained in $55 \%$ yield and separated by fractional crystallization. The meso compound was converted into meso-3, which was desymmetrized into diol (-)-4 by Sharpless asymmetric dihydroxylation [8]. Further transformations allow one to prepare, in principle, all possible stereoisomers of pentadeca-1,3,5,7,9,11,13,15-octols [9].

\footnotetext{
*Paper based on a presentation at the $24^{\text {th }}$ International Symposium on the Chemistry of Natural Products and the $4^{\text {th }}$ International Congress on Biodiversity, held jointly in Delhi, India, 26-31 January 2004. Other presentations are published in this issue, pp. 1-344.

${ }^{\ddagger}$ Corresponding author: Fax: +41 2169393 72; E-mail: pierre.vogel@epfl.ch
} 


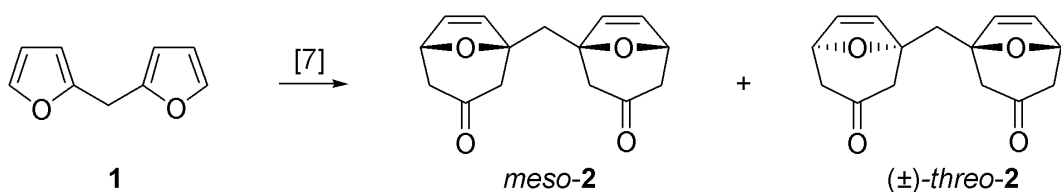

1

meso-2

(士)-threo-2

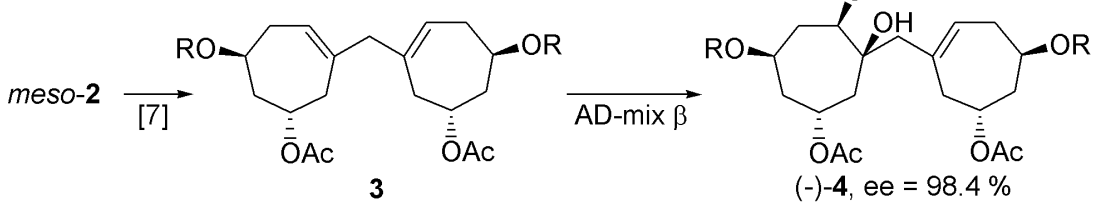

$\frac{\text { 1. } \mathrm{Mg}(\mathrm{OMe})_{2}, \mathrm{MeOH}}{\text { 2. } \mathrm{NalO}_{4}(79 \%)}$

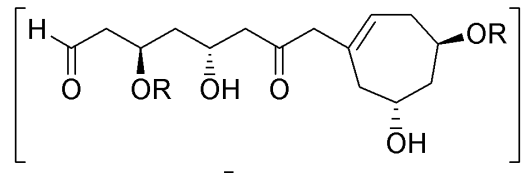

5

$\frac{\mathrm{Me}_{4} \mathrm{NBH}(\mathrm{OAC})_{3}, \mathrm{AcOH}}{\text { or }}$

$\frac{\mathrm{Et}_{2} \mathrm{BOMe}, \mathrm{NaBH}_{4}}{\mathrm{THF}}$<smiles>[R]C1CC=C(CC([X])C[C@@H](O)CC([R])CO)CC(O)C1</smiles>

(-)-6 X: anti-OH $(75 \%)$

(+)-7 X: syn-OH (57 \%)

1. $\mathrm{Me}_{2} \mathrm{C}(\mathrm{OMe})_{2}$, PPTS

2. $\mathrm{PivCl}, \mathrm{pyr}$.

$(-)-6$

3. $\mathrm{NMO}, \mathrm{OsO}_{4}$

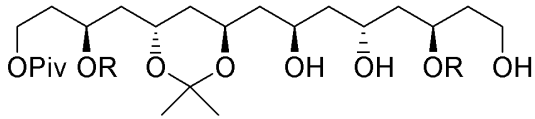

5. $\mathrm{Me}_{4} \mathrm{NBH}(\mathrm{OAc})_{3}$

(-)-8 (30 \%)

$\mathrm{R}=4-\mathrm{MeOC}_{6} \mathrm{H}_{4} \mathrm{CO}$

$\mathrm{Piv}=\mathrm{Me}_{3} \mathrm{CCO}$

(+)-7
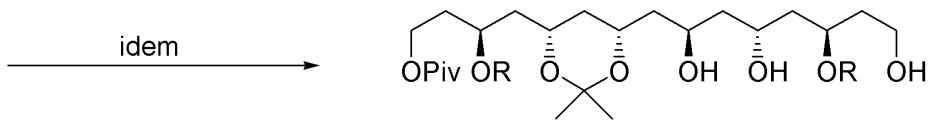

(+)-9

Scheme 1 Examples of long-chain polyketide synthesis by Sharpless desymmetrization.

\section{DESYMMETRIZATION BY SHARPLESS ASYMMETRIC DIHYDROXYLATION}

The oxoaldehyde intermediate 5 resulting from the oxidative cleavage of diol (-)- $\mathbf{4}$ was reduced stereoselectively into triol (-)-6 and (+)-7, applying the conditions of Evans [10] and Narasaka [11], respectively. These compounds have been then converted into semi-protected pentadeca-1,3,5,7,9,11,13,15octols (-)-8 and (+)-9 [7]. These procedures combined with the fact that AD-mix $\alpha$ can be used instead of AD-mix $\beta$ for the desymmetrization of $\mathbf{3}$ allows the preparation of 8 possible stereomeric polyols. Further stereodivergence has been realized in the following way. In the presence of $\mathrm{Mg}(\mathrm{OMe})_{2}$ in $\mathrm{MeOH}$, the bis(4-methoxybenzoate) (-)-10 derived from triol (-)-6 was converted selectively into the monoester (-)-11 in $68 \%$ yield. The acyclic ester is methanolyzed more rapidly than the cyclic ester. After oxidative cleavage of the cycloheptene moiety $(N$-morpholine oxide and a catalytical amount of $\mathrm{OsO}_{4}$, then $\left.\mathrm{Pb}(\mathrm{OAc})_{4}\right)$ pyranose (+)-12 was obtained in $92 \%$ yield. Silylation of (+)-12 with $(i-\mathrm{Pr})_{3} \mathrm{SiCl} /$ imidazole in DMF provided (+)-13 selectively in $\mathbf{7 3} \%$ yield leaving the secondary alcohol free for an esterification with methanesulfonyl chloride and pyridine. This produced a mesylate that underwent smooth $\mathrm{S}_{\mathrm{N}} 2$ displacement by cesium acetate to give acetate (+)-14. Selective desilylation by 
$\mathrm{Bu}_{4} \mathrm{NF}$ liberated the pyranose (+)-15 which could be reduced under Evans' conditions [10] into the semi-protected long-chain polyol (-)-16 (Scheme 2) [9].

$$
\begin{aligned}
& \text { (-)-6 } \quad \frac{\text { 1. } \mathrm{Me}_{2} \mathrm{C}(\mathrm{OMe})_{2}, \mathrm{PPTS}}{2 . \mathrm{Mg}(\mathrm{OMe})_{2} / \mathrm{MeOH}} \\
& 40^{\circ} \mathrm{C}(68 \%)
\end{aligned}
$$<smiles>[R20]C1CC=C(CC2CC(CC([R])CO)OC(C)(C)O2)CC(O)C1</smiles>

$(-)-10 \mathrm{R}^{\prime}=\mathrm{R}=4-\mathrm{MeOC}_{6} \mathrm{H}_{4} \mathrm{CO}$

$(-)-11 \mathrm{R}^{\prime}=\mathrm{H}, \mathrm{R}=4-\mathrm{MeOC}_{6} \mathrm{H}_{4} \mathrm{CO}$

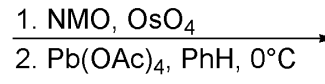

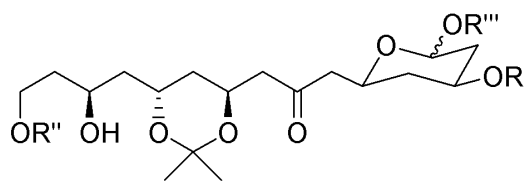

$(+)-12 \mathrm{R}^{\prime \prime}=\mathrm{R}^{\prime \prime \prime}=\mathrm{H}$

$(+)-13 R^{\prime \prime}=R^{\prime \prime \prime}=$ TIPS

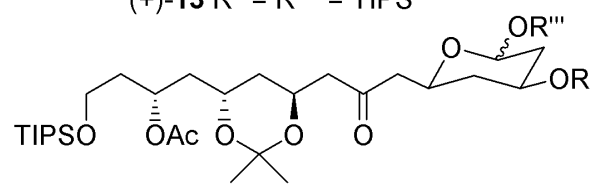

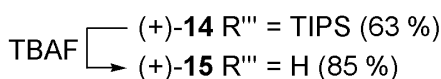

Scheme 2 Selective inversion of acyclic secondary alcohol and polyketide synthesis.

\section{DOUBLE OXIDATIVE CLEAVAGE}

The racemic diketone ( \pm )-threo-2, which can be separated readily from meso-2, has been reduced into diol ( \pm )-17 with K-Selectride in THF. Kinetic resolution with Candida cylindracea lipase-catalyzed transesterification with vinyl acetate allows one to obtain enantiomerically enriched diacetate $(+)-\mathbf{1 8}$ (98\% ee) and diol (-)-17 (98\% ee) [12]. Diacetate (+)-18 has been converted into (-)-19 (Scheme 3) [13] by the same procedure [9] as that converting meso-2 into 3 (Scheme 1). Double ozonolysis of (-)-19, followed by the diastereoselective reduction of the resulting double $\beta$-hydroxyketone intermediate applying Evans' [10] and Narasaka's [11] conditions allows the preparation of enantiomerically pure $(98 \%$ ee) polyols (-)-20 (65\%) and (-)-22 (60\%), respectively. Differentiation of the terminal centers of these 15-carbon polyketides is thus possible by control of temperature and excess of the reducing agent. For instance, pyranose (-)-21 can be isolated in $65 \%$ yield from (-)-19 (Scheme 3) [13]. 

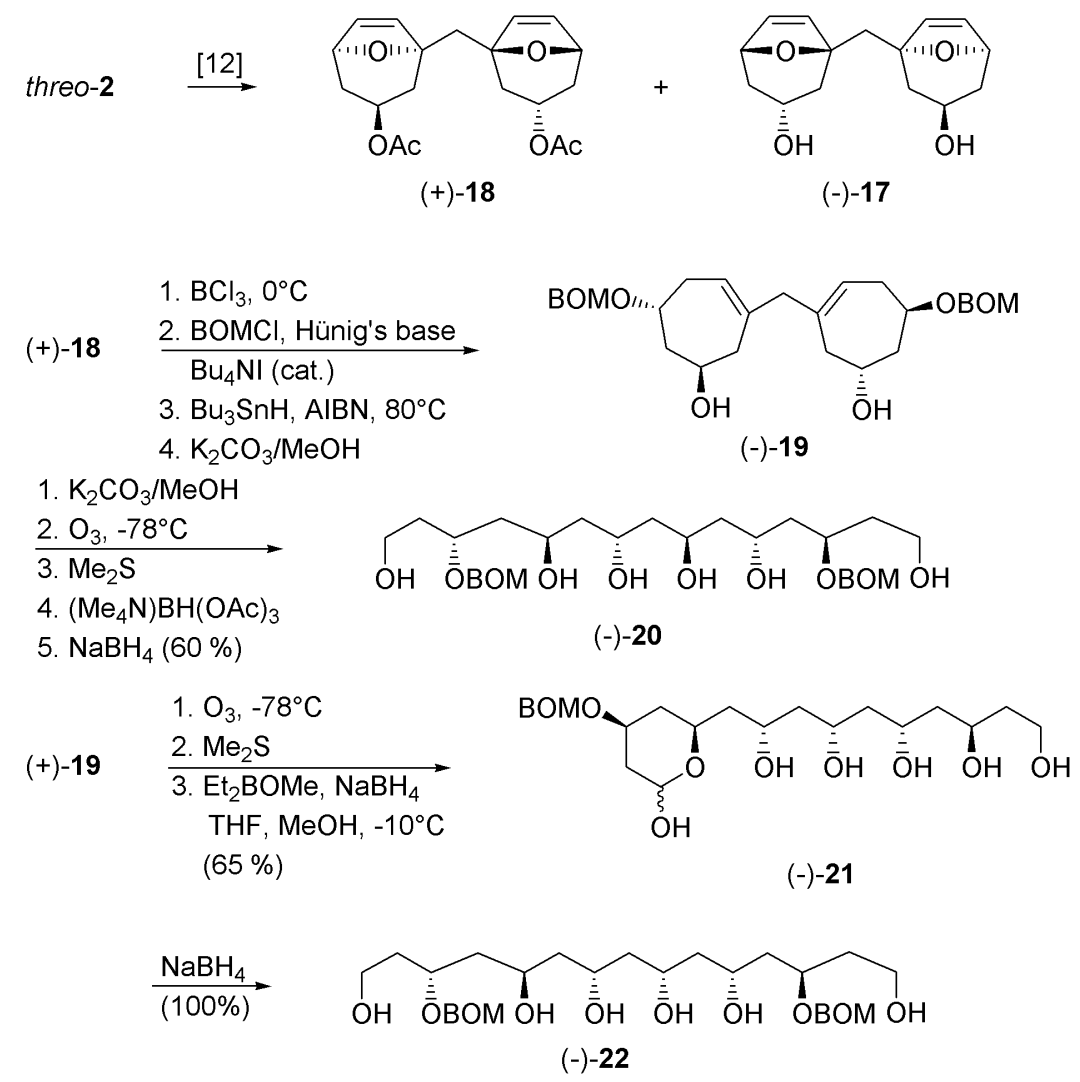

Scheme 3 Long-chain polyols via double oxidative cleavage.

\section{FURTHER STEREODIVERSITY}

We disclose here that the double oxidative cleavage of $\mathbf{3}$ (with $\mathrm{R}=\mathrm{BOM}$ ) leads to meso polyol intermediates that can be resolved by lipase-catalyzed acetylation (Scheme 4). Methanolysis of 3 $(\mathrm{R}=\mathrm{BOM})$ (derived from endo-23 [9]) gave diol 24 (52\% based on endo-23) that was submitted to ozonolysis and subsequent Narasaka's reduction furnishing a 6:1 mixture of hexols $\mathbf{2 5}$ and $\mathbf{2 6}$ in $62 \%$ yield. Pure 25 was obtained by flash chromatography and was converted into the bis-acetonide 27 (77\%). In pure vinyl acetate and in the presence of $C$. cyclindracea lipase, the monoacetate (-)-28 (90\% ee, Mosher's ester) was obtained in $83 \%$ yield

We disclose also that $1,1^{\prime}$-methylenedi[( $\left.1 R, 1^{\prime} S, 3 R, 3 ' S, 5 S, 5^{\prime} R\right)$-8-oxabicyclo[3.2.1]oct-6-en-3-ol] (exo-23) can be obtained in $60 \%$ yield, with 99:1 exo/endo diastereoselectivity, by direct reduction of diketone meso-2 with $\mathrm{SmI}_{2}$ in THF $\left(-78-20{ }^{\circ} \mathrm{C}\right)$. Similar yield and diastereoselectivity were observed using $i-\mathrm{PrOH} / \mathrm{Ti}(-\mathrm{O}-i-\mathrm{Pr})_{4}$ as reducing agent. The latter could be applied to the 45:55 mixture of diketone meso-2 and ( \pm -threo-2. After acetylation $\left(\mathrm{Ac}_{2} \mathrm{O}\right.$, pyr, DMAP) an inseparable mixture of diacetates was obtained. It was submitted to the usual ethereal bridge-opening conditions $\left(\mathrm{BCl}_{3}, \mathrm{CH}_{2} \mathrm{Cl}_{2}\right.$, quenching with $\mathrm{BOMCl}$ ) that gave products 30 and $( \pm)-\mathbf{3 1}$ that were readily separated by flash chromatography (Scheme 5). The meso compound 30 was dechlorinated, then methanolyzed and submitted to ozonolysis and reductive work-up under Evans' conditions. This gave a major pyranose ( \pm )-32, the optical resolution of which is under study at this moment. One enantiomer of $( \pm)-\mathbf{3 2}$ is a potential precursor for the synthesis of oxo-polyene macrolide RK-397 [14,15]. 


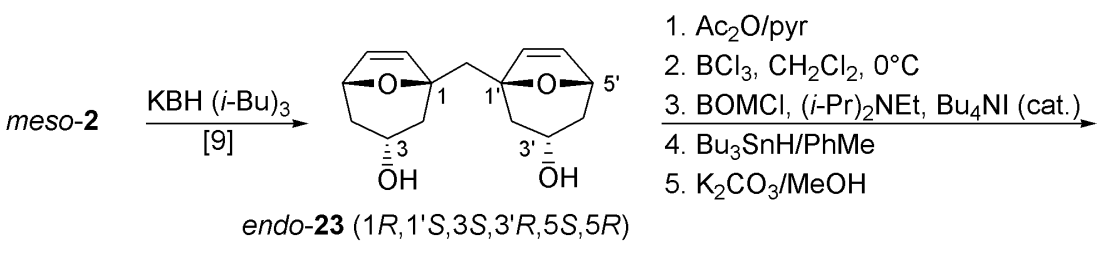<smiles>[R4]O[C@H]1CC=C(CC2=CC[C@@H](O[R16])C[C@H](O)C2)C[C@@H](O)C1</smiles>

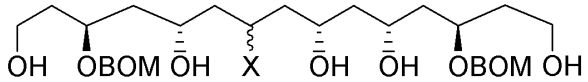

$$
\begin{aligned}
& 25 \mathrm{X}=\text { syn-OH } \\
& 26 \mathrm{X}=\text { anti- } \mathrm{OH}
\end{aligned}
$$



Scheme 4 Desymmetrization of meso-derivatives by lipase-catalyzed acetylation.

$$
\text { meso-2 + threo-2 }
$$<smiles>[Y]O[R10]([H])=O</smiles>

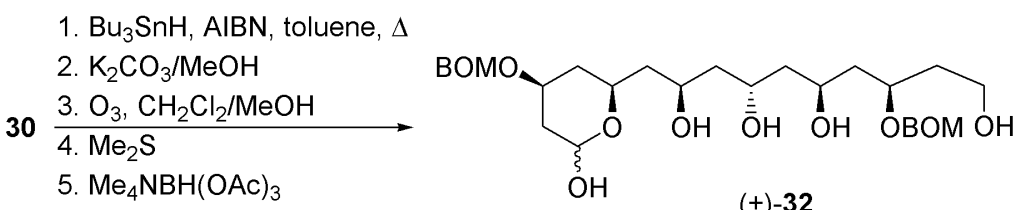

Scheme 5 Synthesis of 1,1'-methylenebis(cis-4,6-dihydroxycyclohept-1-ene) derivatives and their conversion to long-chain polyketides. 


\section{CONCLUSION}

Starting with inexpensive furan and furfuryl alcohol, a noniterative approach to the synthesis of longchain polyketides has been developed. High enantioselectivities and stereodiversity are realized applying simple procedures. They rely upon the Sharpless asymmetric dihydroxylation of 3,5dihydroxycyclohept-1-ene systems, on diastereoselective reductions of aldols using the Narasaka's or Evans' conditions, and/or on kinetic resolution using lipase-catalyzed acylations.

\section{ACKNOWLEDGMENTS}

This work was supported by the Swiss National Science Foundation and the Office Fédéral de l'Education et de la Science (OFES, COST D13/010/01), which are gratefully acknowledged. We thank also the University of Seville for a grant to one of us (A.T.C.A.).

\section{REFERENCES}

1. (a) S. Omura and H. Tanaka. Macrolide Antibiotics: Chemistry, Biology and Practice, Academic Press, New York (1984); (b) S. D. Rychnovsky, G. Griesgraber, R. Schlegel. J. Am. Chem. Soc. 117, 197 (1995); (c) T. I. Richardson and S. D. Rychnovsky. J. Org. Chem. 61, 4219 (1996); (d) B. H. Lipschutz, B. Ullman, C. Lindsley, S. Recchi, D. J. Buzard, D. Dickson. J. Org. Chem. 63, 6092 (1998); (e) J. Pawlak, P. P. Sowinski, E. Borowski, P. Gariboldi. J. Antibiot. 48, 1034 (1995); (f) G. J. McGarvey, J. A. Mathys, K. J. Wilson, K. O. Overly, P. T. Buonova, P. G. Spours. J. Org. Chem. 60, 7778 (1995); (g) T. Mukhopadhyay, E. K. S. Vijayakumar, S. R. Nadkarni, H. W. Fehlhaber, H. Kogler, S. Petry. J. Antibiot. 57, 582 (1998).

2. For recent proposal, see e.g.: (a) S. Allerheiligen and R. Brückner. Liebigs Ann./Receuil 1667 (1997); (b) C. Schneider. Angew. Chem., Int. Ed. 37, 1375 (1998); (c) D. Muñoz-Torero and R. Brückner. Eur. J. Org. Chem. 1031 (1998); (d) S. D. Rychnovsky, O. Fryzman, U. R. Khine. Tetrahedron Lett. 40, 41 (1999); (e) C. Schneider and M. Rehfeuter. Chem. Eur. J. 5, 2850 (1999); (f) K. B. Jørgensen, T. Suenaga, T. Nakata. Tetrahedron Lett. 40, 8855 (1999); (g) D. Enders and T. Hundertmark. Tetrahedron Lett. 40, 4169 (1999); (h) A. B. Smith III and S. M. Pitram. Org. Lett. 1, 2001 (1999); (i) G. J. McGarvey, J. A. Mathys, K. J. Wilson. Tetrahedron Lett. 41, 6011 (2000); (j) P. B. Greer and W. A. Donaldson. Tetrahedron Lett. 41, 3801 (2000); (k) P. A. Wender and B. Lippa. Tetrahedron Lett. 41, 1007 (2000); (1) J. Kiegiel, J. Józwik, K. Wozniak, J. Jurczak. Tetrahedron Lett. 41, 4959 (2000); (m) A. G. M. Barrett, D. C. Braddock, P. D. de-Koning, A. J. P. White, D. J. Williams. J. Org. Chem. 65, 375 (2000); (n) S. T. Sarraf and J. L. Leighton. Org. Lett. 2, 403 (2000); (o) M. J. Zacuto and J. L. Leighton. J. Am. Chem. Soc. 122, 8587 (2000); (p) S. I. Kiyoota, M. A. Hena, T. Yabukami, K. Murai, F. Goto. Tetrahedron Lett. 41, 7511 (2000); (q) S. Bouzbouz and J. Cossy. Org. Lett. 2, 3975 (2000); Org. Lett. 2, 501 (2000); (r) T. Trieselmann and R. W. Hoffmann. Org. Lett. 2, 1209 (2000); (s) I. Paterson and L. A. Collett. Tetrahedron Lett. 42, 1187 (2001); (t) T. J. Hunter and G. A. O’Doherty. Org. Lett. 3, 1049 (2001); (u) C. J. Sinz and S. D. Rychnovsky. Angew. Chem., Int. Ed. 40, 3224 (2001); (v) D. J. Kopecky and S. D. Rychnovsky. J. Am. Chem. Soc. 123, 8420 (2001); (w) S. A. Burova and F. E. McDonald. J. Am. Chem. Soc. 124, 8188 (2002).

3. M. Lautens, S. Ma, A. Yee. Tetrahedron Lett. 36, 4185 (1995).

4. (a) T. F. J. Lampe and H. M. R. Hoffmann. Chem. Commun. 1931 (1996); (b) R. Dunkel and H. M. R. Hoffmann. Tetrahedron Lett. 55, 8385 (1999); (c) R. Dunkel, M. Mentzel, H. M. R. Hoffmann. Tetrahedron 53, 14929 (1997); (d) A. Vakalopoulos and H. M. R. Hoffmann. Org. Lett. 3, 177 (2001); (e) A. Vakalopoulos, T. F. J. Lampe, H. M. R. Hoffmann. Org. Lett. 3, 929 (2001).

5. A. M. Montaña, F. Garcia, P. M. Grima. Tetrahedron 55, 5483 (1999). 
6. H. Kaku, M. Tanaka, Y. Norimine, Y. Miyashita, H. Suemune, K. Sakai. Tetrahedron: Asymmetry 8, 195 (1997).

7. (a) M.-E. Schwenter and P. Vogel. Chem. Eur. J. 6, 4019 (2000); (b) K. T. Meilert, M.-E. Schwenter, Y. Schatz, S. R. Dubbaka, P. Vogel. J. Org. Chem. 68, 2964 (2003).

8. K. B. Sharpless, H. C. Kolb, M. S. Van Nieuwenhze. Chem. Rev. 94, 2483 (1994).

9. M.-E. Schwenter and P. Vogel. J. Org. Chem. 66, 7869 (2001).

10. D. A. Evans, K. T. Chapman, E. M. Carreira. J. Am. Chem. Soc. 110, 3560 (1988).

11. (a) K. Narasaka and F. G. Pai. Tetrahedron 40, 2233 (1984); (b) K. N. Chen, G. E. Hardtmann, K. Prasad, O. Repic, M. J. Shapiro. Tetrahedron Lett. 28, 155 (1987).

12. A. G. Csákÿ and P. Vogel. Tetrahedron: Asymmetry 11, 4935 (2000).

13. S. Gerber-Lemaire and P. Vogel. Eur. J. Org. Chem. 2959 (2003).

14. K. Kobinata, H. Koshino, T. Kudo, K. Isono, H. Osada. J. Antibiot. 46, 1616 (1993).

15. C. Schneider, F. Tolksdorf, M. Rehfeuter. Synlett 2098 (2002). 